\title{
Disegno, Paradigma Informatico e Intelligenza Artificiale
}

Gianluca Emilio Ennio Vita

Abstract

Che il computer abbia cambiato la pratica, la teoria e probabilmente anche il significato del disegnare è cosa nota. La mutazione è con tutta evidenza ancora in atto e continuerà ad esserlo negli anni a venire ed è altrettanto noto che il passaggio dalla carta al computer abbia comportato la perdita di molte delle qualità e specificità del pensiero disegnativo.

Siamo ancora in una fase di 'digestione' del primo salto di paradigma, rappresentato dal passaggio dal disegno 'classico' a quello 'informatizzato' e stiamo già per assistere ad un nuovo salto di paradigma tecnologico e concettuale: quello dovuto allo sviluppo degli algoritmi della cosiddetta Intelligenza Artificiale.

Come ogni rivoluzione tecnologica anche questo passaggio presenterà molte incognite accompagnate dalla speranza di poter ottenere strumenti più vicini al pensare creativo architettonico che a quello ingegneristico-informatico tipico degli strumenti attuali.

Parole chiave

intelligenza artificiale, disegno, go, algoritmi.

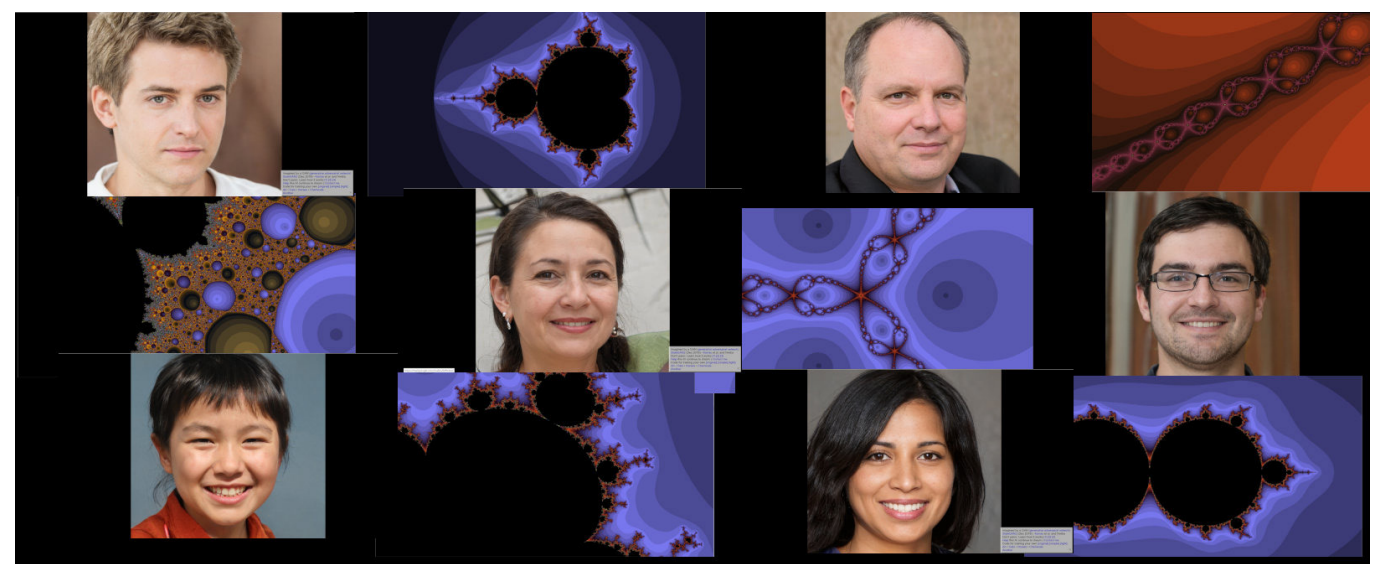




\section{Introduzione}

Ancora oggi quando guardiamo la 'pipa che non è una pipa' disegnata da Magritte ci interroghiamo su cosa accada alla nostra mente quando rappresentiamo un oggetto. Ci chiediamo cosa sia in realtà quella cosa che è ma che allo stesso tempo non è, e poi cosa sia l'immaginare, il pensare, il progettare e quindi l'intelligenza stessa.

Crediamo che il disegnare non possa essere considerato una cosa diversa dal pensare e dal progettare e riteniamo necessario sostenere, con forza, che il disegno è progetto e pensiero nella sua più alta espressione.

Non si tratta di malinconie di un secolo passato, né di considerazioni superflue in questi anni in cui la forza bruta della tecnica travolge ogni cosa [Focault 1983].

Non è umanamente possibile rispondere alla domanda posta dal dipinto di Magritte e comprendere davvero cosa sia l'intelligenza, la mente, il pensiero. Per comprenderlo sarebbe forse necessaria una 'livello superiore', non necessariamente mistico.

Fig. I. Un esempio di volto umano creato da I.A. <https://

thispersondoesnotexist. $\mathrm{com} />$ (consultato 3 marzo 202I).
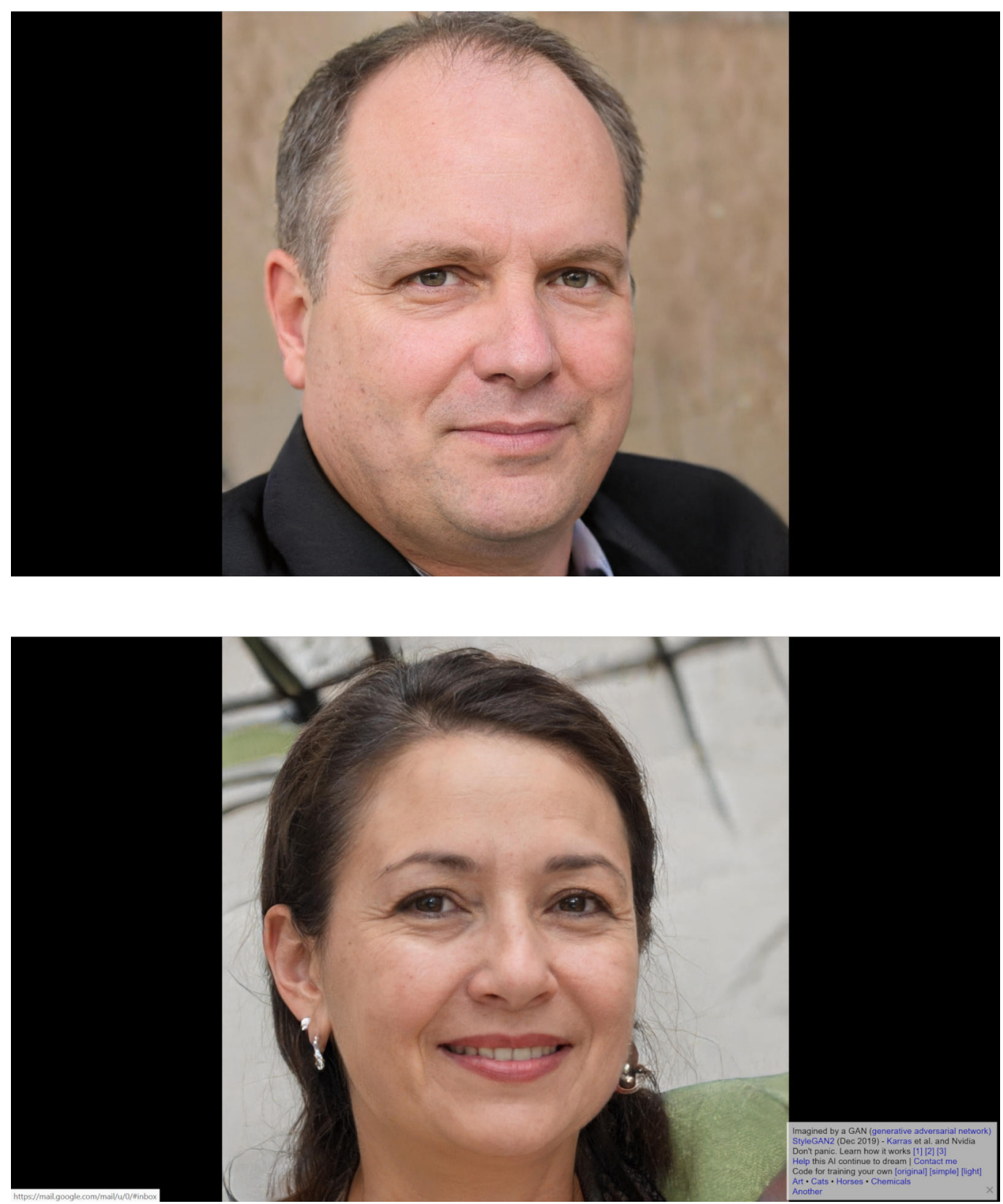
II matematico Gödel ha dimostrato come un sistema non possa essere auto dimostrante, perché un sistema (o un'entità) possa essere dimostrata è necessario che vi sia un'altra entità superiore ad essa. Gödel parlava di una entità matematica, ma il concetto è certamente estendibile a metafora della condizione umana [Hofstadter 1979].

Per cercare di leggere e comprendere questo metaforico livello superiore il disegno resta la più straordinaria forma di esplorazione che abbiamo a disposizione. Lo strumento che più di ogni altro ci mette in contatto con noi stessi, che ci aiuta a capire chi e cosa siamo e ad avvicinarci alla comprensione della natura dell'intelligenza.

II disegno ci consente di andare oltre lo specchio e ci mostra le parti più nascoste di noi stessi ma al cambiare dello strumento cambia anche quello che si vede e con esso quello che del nostro essere umani siamo in grado di comprendere [Anceschi 1988].

La rivoluzione del disegno informatico, quindi, non ha solo rappresentato un passaggio tecnico e pratico da un modo di disegnare ad un altro, ha sancito (così come ha fatto la
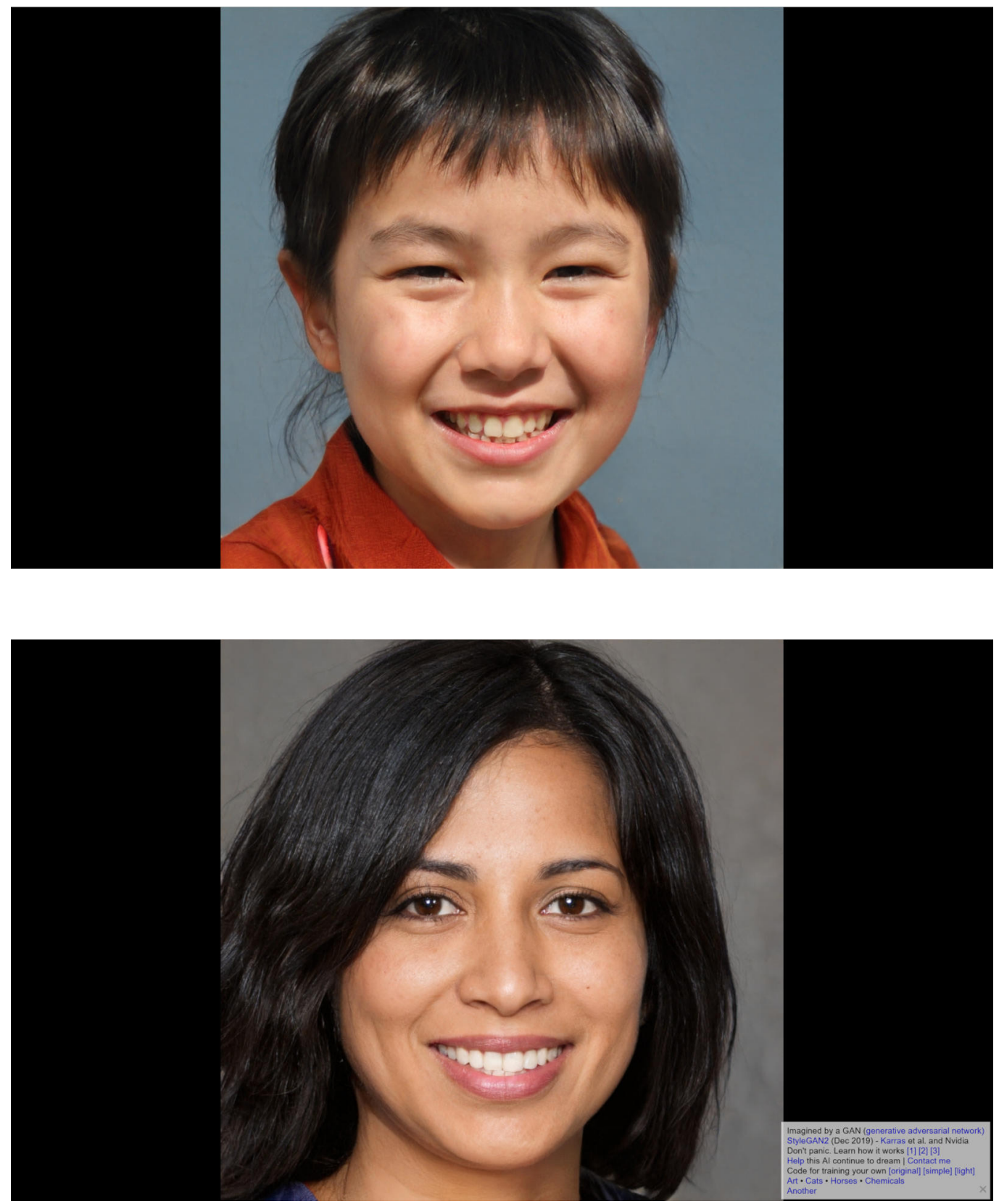
prospettiva a suo tempo) [Panofsky 200 I] un salto di paradigma nel modo di pensare e concepire il nostro universo mentale e la nostra essenza umana.

Mentre siamo ancora in una fase di 'digestione' del primo salto di paradigma dal disegno 'classico' a quello 'informatizzato' stiamo però già per assistere ad un nuovo salto tecnologico e concettuale: quello dovuto allo sviluppo degli algoritmi della cosiddetta Intelligenza Artificiale, che rappresentano un'incognita ma anche la possibilità di liberarci dai limiti del disegno digitale attuale.

\section{Il cambio di paradigma digitale}

È evidente che il disegnare sia in una fase di cambio di paradigma e che tecniche digitali stiano cambiando l'idea stessa di disegno, si può anzi parlare già al passato di questo avvenimento. Le tecniche digitali hanno cambiato il modo di disegnare e di concepire l'atto

Fig. 5. Un esempio di volto umano creato da I.A. $<$ https:// thispersondoesnotexist. com/ $>$ (consultato il 3 marzo 2021).
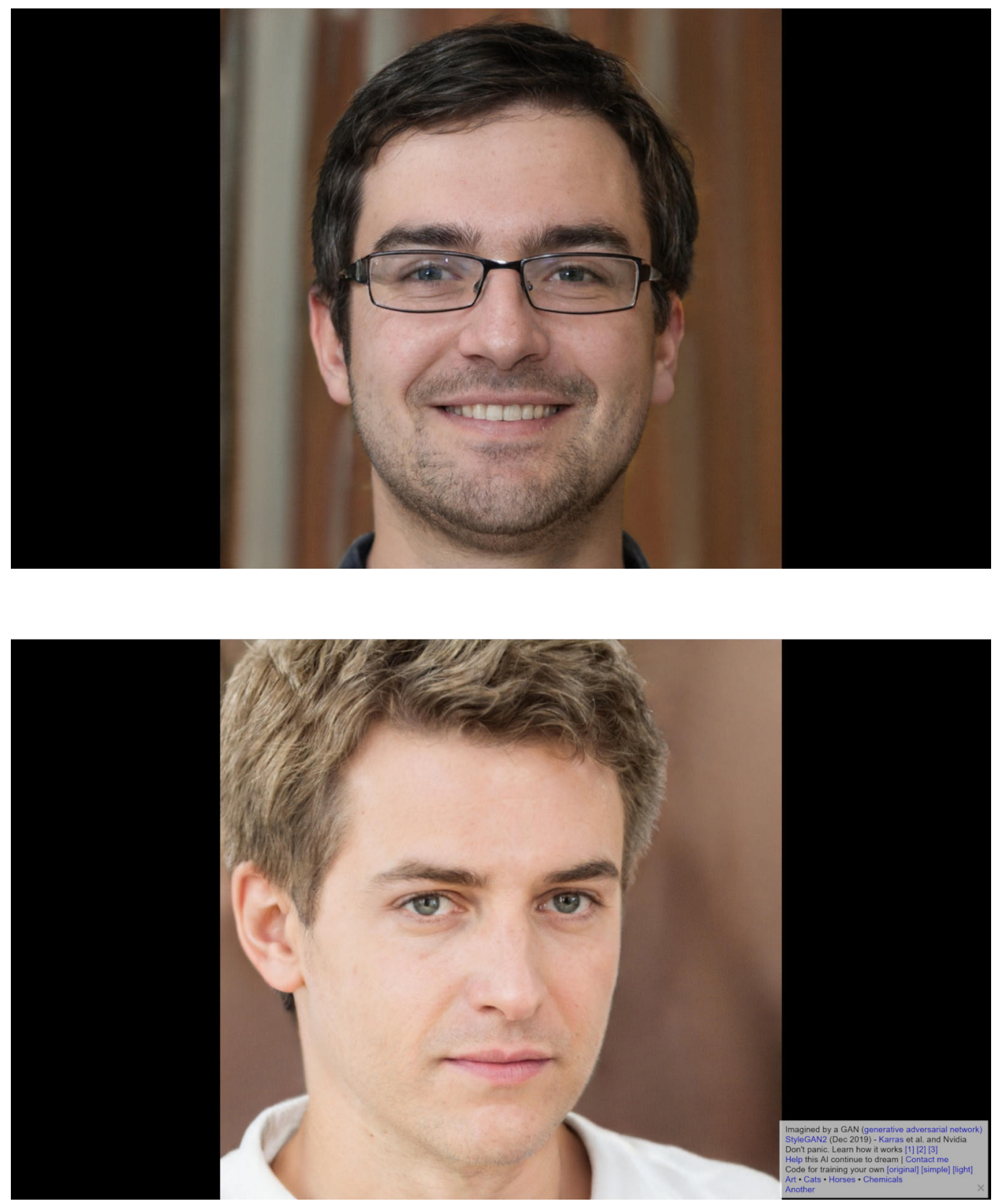


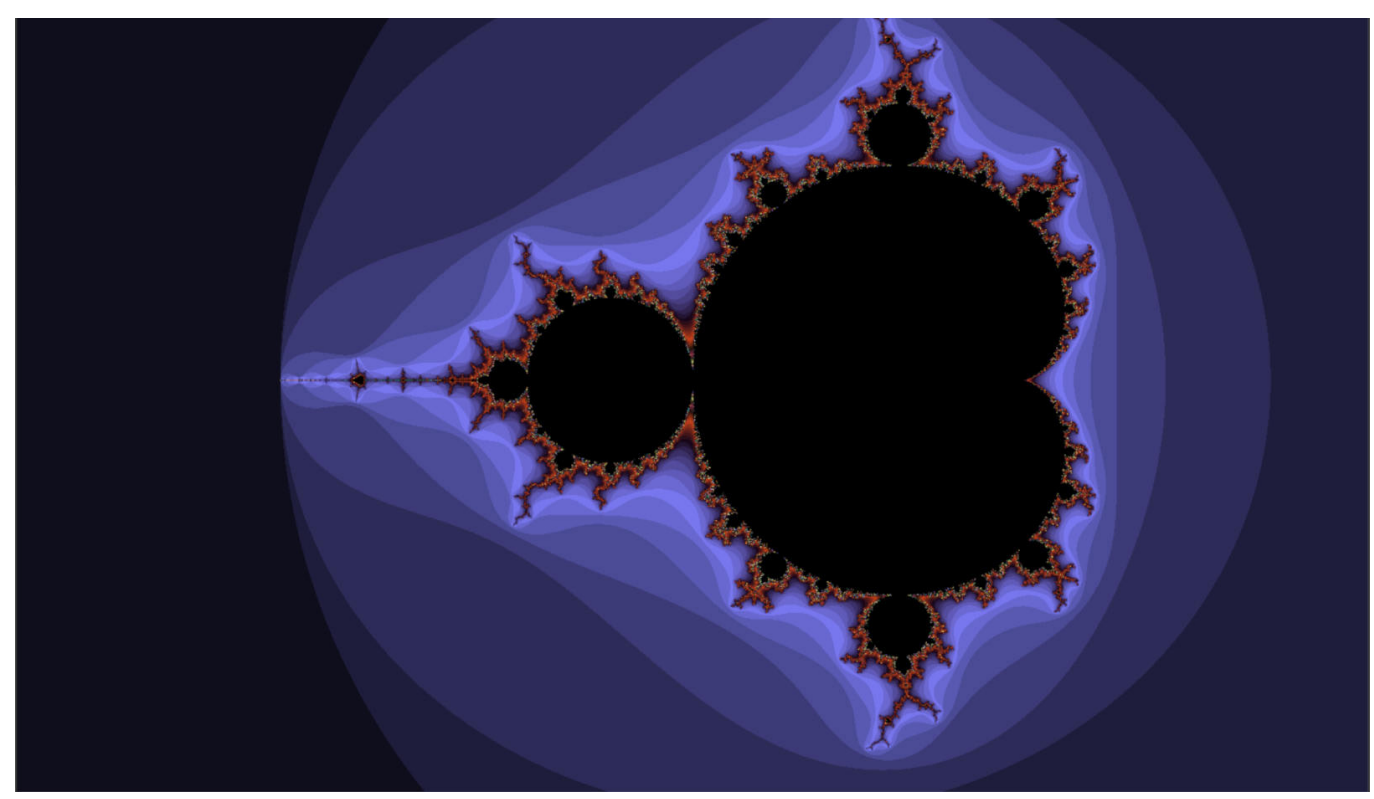

stesso del disegnare e lo stanno cambiando tuttora, con grandi problemi causati dal fatto (si perdoni l'eccesso di semplificazione) che gli strumenti di disegno digitale non sono stati fatti da disegnatori ma da informatici.

Tutto il processo di sviluppo dei principali software di disegno ha seguito, a partire dagli anni '70 una parabola uniforme in cui si è iniziato a 'mettere gli strumenti reali dentro il computer'. Questo processo è evidente ancora oggi nei comandi evidentemente ispirati al tecnigrafo come in Autocad, o alla camera oscura come in Photoshop.

Ma si è trattato solo di una prima fase, l'agire informatico è poi diventato sempre più astratto seguendo logiche e strutture mentali che non sono quelle del disegnatore [Norman 1988]. Non potendo approfondire qui questo tema, pensiamo basti come esempio porre l'attenzione sulla furibonda necessità di precisione che il disegnare con un qualsiasi software Cad richiede. II disegno Cad vettoriale è per molti l'archetipo del 'disegnare col computer' e richiede una costante ossessiva e folle fornitura di coordinate esattissime: Distanza! Distanza! Distanza! II disegnatore non ragiona così. Per il disegnatore viene prima la proporzione e solo dopo la misura. Possiamo dire che senza dubbio oggi usiamo strumenti di disegno non adeguati che violentano la natura stessa del disegnare. A volte capita di farsi prendere dall'angoscia claustrofobica di trovarsi in un flusso di cui conosciamo l'inizio e solo possiamo intuire la fine con la sensazione di potere solo percorrere un solo tragitto, stabilito e deciso da chi produce lo strumento infor-

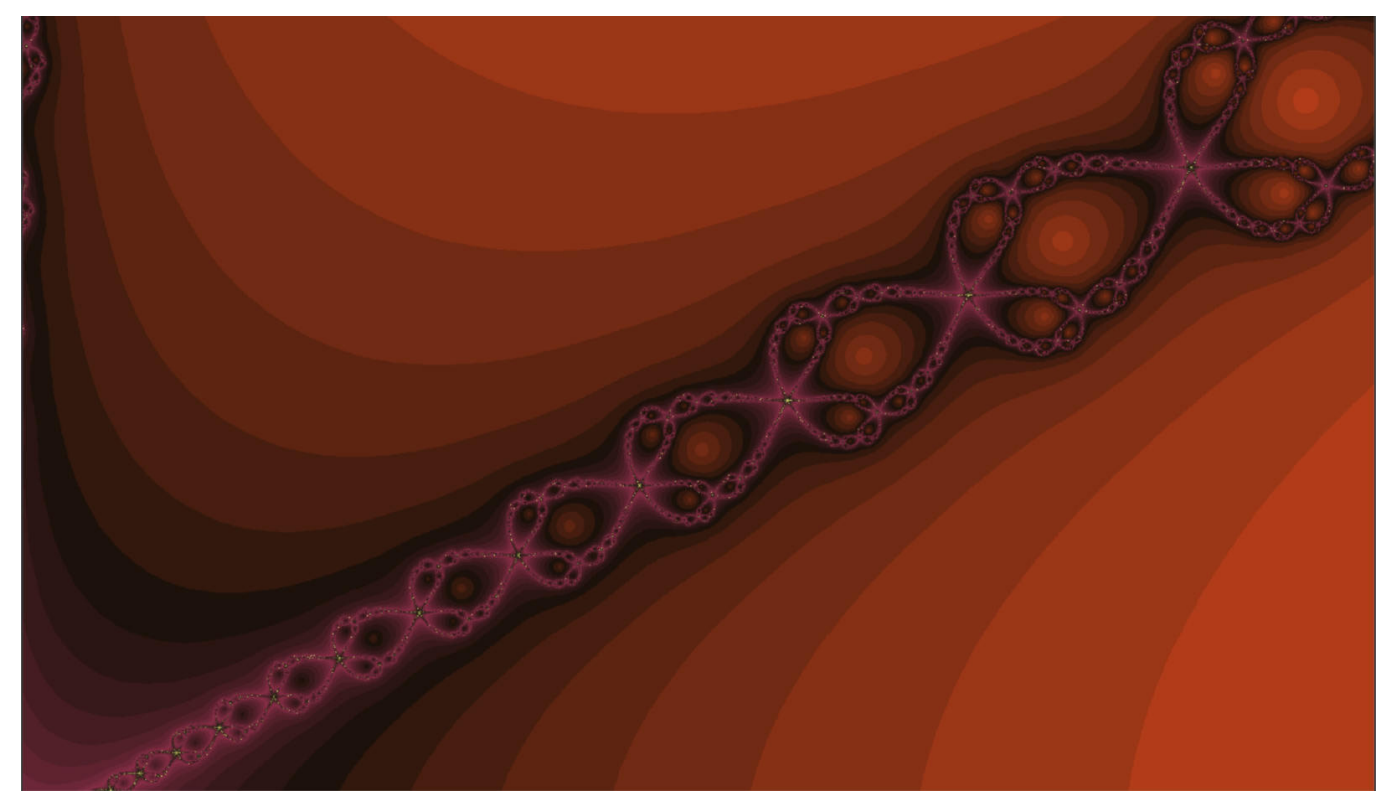




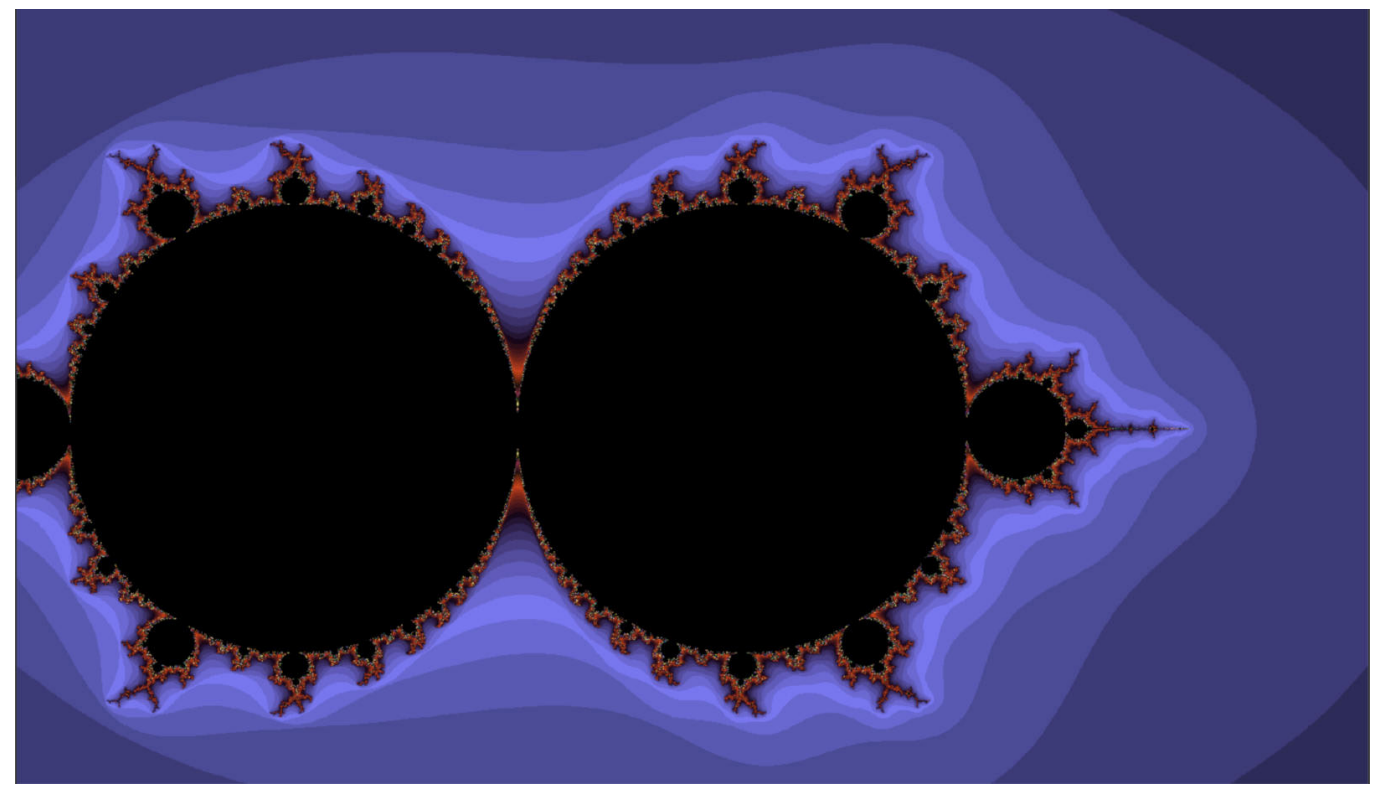

matico. Ribadiamo che non si tratta di un processo di semplice sostituzione di un attrezzo con un altro perché, "il media è il messaggio" [Mc Luhan 1964] o se si preferisce, perché disegnare è pensare, immaginare ed esplorare il 'livello superiore' quindi se si disegna male si pensa male. Non che siano mancati tentativi di avvicinare il software al pensare umano, ma i risultati sono ben lontani dall'essere, a nostro avviso, soddisfacenti. Interessante può essere l'esempio del software SketchUp che ha tentato, con qualche successo, di uscire dalla logica 'una funzione - un comando' per proporre un'interazione in cui il software cerca di indovinare quello che la Persona (termine che preferiamo all'odioso 'utente') intende fare dalla posizione e dal movimento del mouse.

Possiamo anche accennare, a titolo di esempio, ai software BIM che pur cercando, meritoriamente, di rappresentare un metodo di semplificazione e razionalizzazione del disegnare edifici con il computer crollano sotto il peso della loro eccessiva complessità.

Eccellente il concetto di base, che si fonda sull'idea che se disegno una linea e dico al com-

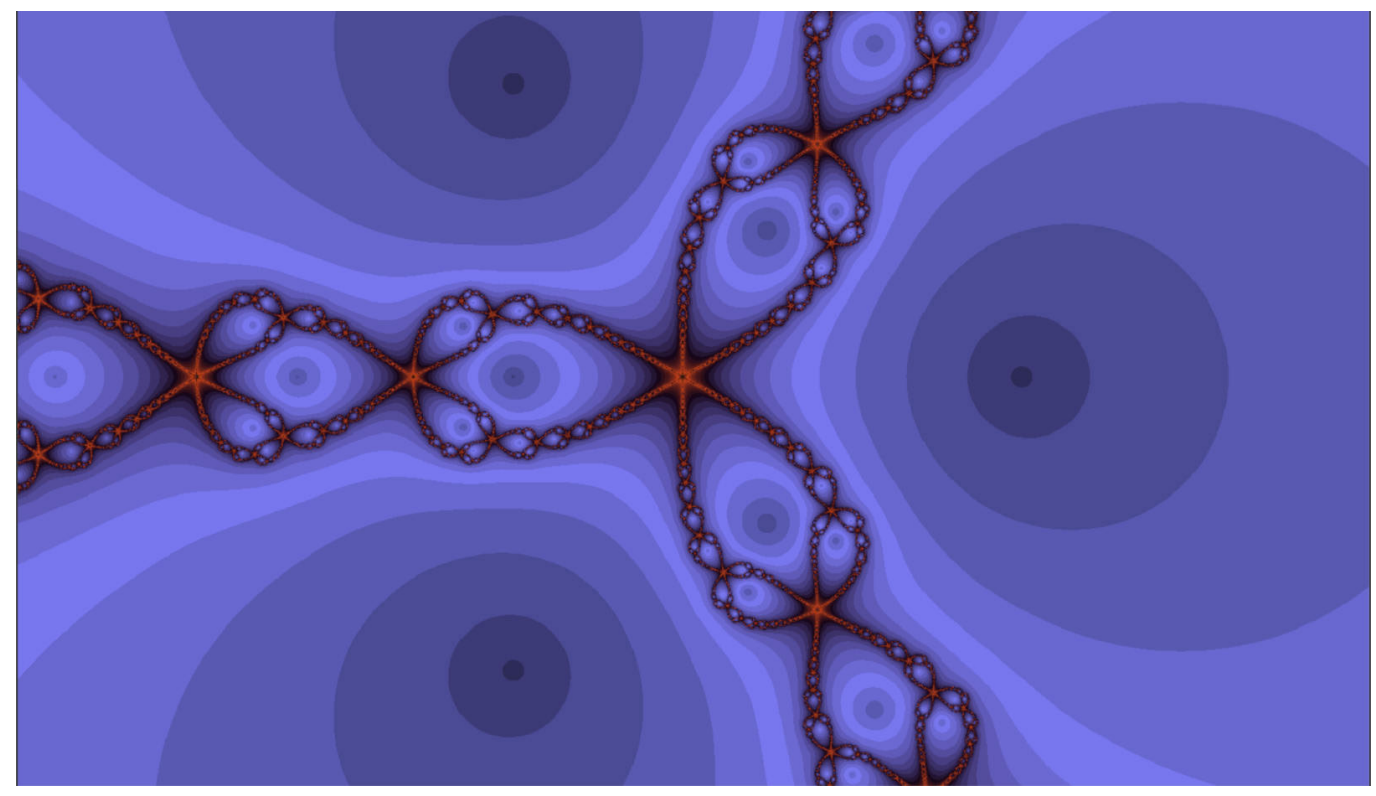


puter che quella linea è un muro, e poi gli dico che il muro è fatto con certi materiali ho un modello infinitamente modificabile ed aggiornabile in cui posso poi inserire porte, finestre, aggiungere e sottrarre piani eccetera. II tutto in modo interattivo con il grande vantaggio di non dovere rifare i disegni tecnici ogni volta.

Purtroppo, il risultato di questo sforzo, per motivi dovuti alla natura profonda del processo $B I M$, è il tentativo di fare un modello in scala I: I dell'edificio che trasforma il software da uno strumento di disegno in una sorta di enorme file Excel tridimensionale.

Se i programmatori avessero letto la novella di Borges sullimperatore cinese che volle realizzare un modello in scala I:I dell'impero, forse il risultato sarebbe stato migliore.

In questo contesto di strumenti di disegno non adatti al suo modo di pensare la figura dell'architetto non si trova solamente in forte necessità di adattamento (cosa alla quale orami è abituato da tempo e che anzi, come sostenuto da Mario Carpo [Carpo 20 I7], ha saputo gestire con grande abilità in quello che lui definisce il primo digital turn) ma si trova, diciamolo senza mezzi termini, in pericolo di estinzione perché gli strumenti che usa veicolano un modo di pensare che è profondamente diverso dal suo.

Ci troviamo in un'epoca in cui lo strumento digitale cerca, in modo più o meno consapevole di erodere il carattere stesso del pensiero dell'architetto come connessione tra il pensiero artistico e quello tecnologico e di trasformarlo in una sorta di esecutore-decoratore cui vengono demandati, al massimo, compiti marginali di 'moda' e 'gusto'.

Tutto il resto, la cultura e il sapere profondo dell'architettura paiono sofismi da iniziati, discorsi tra filosofi o maestri di ikebana, dediti ad un'estetica astratta e distaccata.

\section{Le macchine stanno imparando a disegnare?}

Possiamo sperare che lo sviluppo della cosiddetta intelligenza artificiale e degli algoritmi ad essa collegati potrà, in un futuro prossimo, consentirci di utilizzare strumenti meno legati a modi di pensare 'rigidi' che ci vengono imposti dai metodi di disegno digitale di cui abbiamo parlato finora? Le macchine hanno oramai superato la capacità umana nel gioco degli scacchi, e anche l'orientale gioco del Go, apparentemente ancora più profondo nell'esplorare l'intuizione umana, è stato conquistato da una intelligenza artificiale.

Giocare a scacchi, o a Go, per la mente umana prevede l'adozione di 'accordi' di pensiero che vanno oltre all'analisi delle mosse possibili. II maestro di scacchi gioca pensando composizioni funzionali che non possono essere descritte come un albero delle possibilità (se io

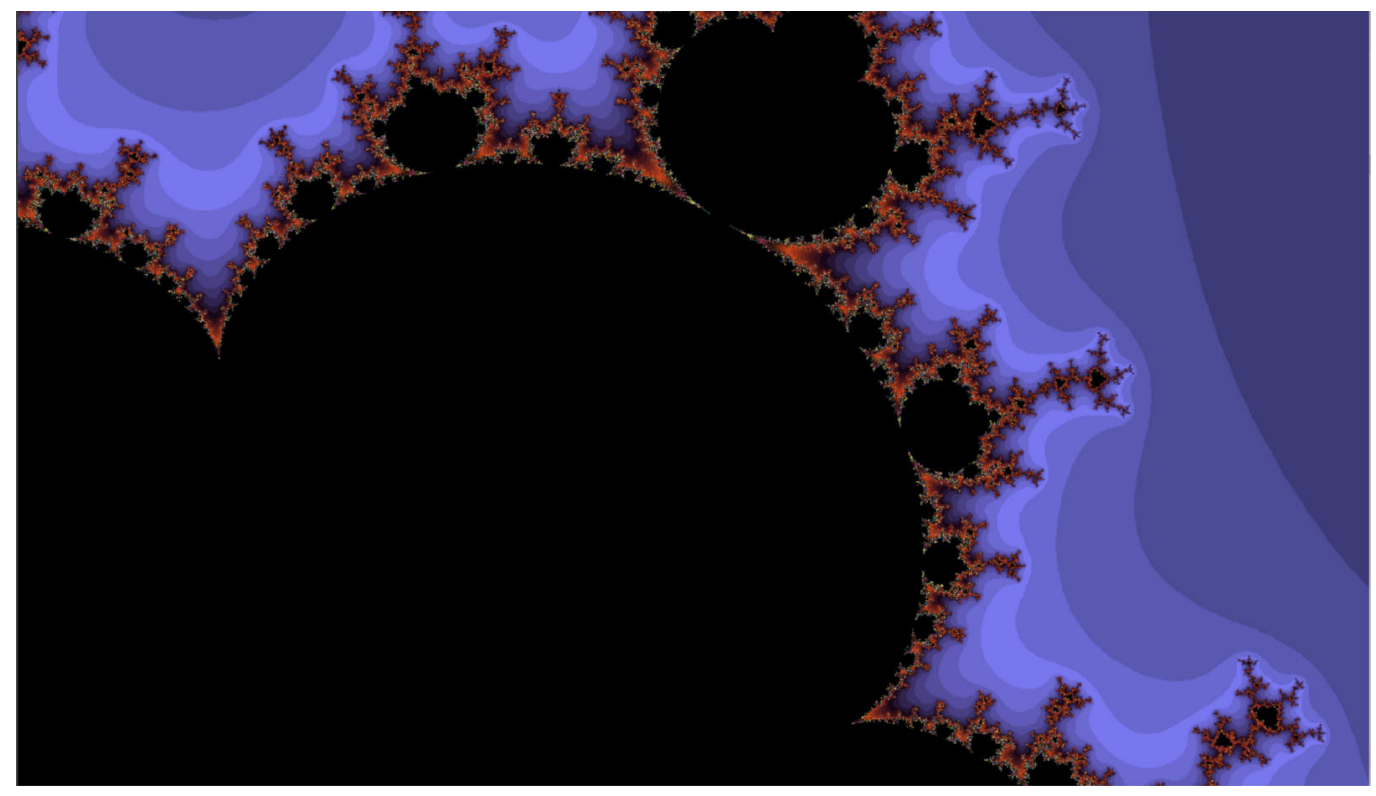


faccio questo, l'altro fa quello... allora io faccio quest'altro ecc...) ma come configurazioni di forme virtuali che portano a intuire la forma della mossa successiva.

"La mossa 37 era stata così scioccante che Lee era arrivato a chiedersi cosa fosse la creatività nel Go. Dopo aver perso anche la seconda partita, aveva deciso di riunirsi con alcuni professionisti del Go e analizzare l'incontro". E discutere del senso e della filosofia del gioco stesso (dalla descrizione della prima partita in cui l'intelligenza artificiale Alpha GO ha battuto il campione mondiale di Go Lee Se-Dol).

Che relazione lega, però, la pratica del disegno con quello che accade al gioco del Go o degli scacchi? La relazione sta diventando velocemente evidente.

Se si cerca sul web la pagina thispersondoesnotexist [I] appaiono, ricaricando più volte la pagina, immagini di persone che, semplicemente, non esistono. Sono immagini create in modo totalmente artificiale attraverso l'uso di 'algoritmi contrastanti' che compiono una operazione impressionante, creando volti artificiali quasi sempre perfettamente credibili ed indistinguibili da volti reali. Non si tratta di una operazione di composizione come quella che si potrebbe fare con Photoshop, si tratta di una vera e propria operazione di creazione archetipica (figg. I-6).

Si tratta di una operazione di disegno che si fa fatica a non definire intelligente. La macchia riesce ancora una volta ad appropriarsi di una operazione finora riservata alle capacità dell'intelletto umano: disegnare volti, una delle operazioni che più caratterizza il pensiero umano e lo distacca dalla bestialità. È certo che la mente umana abbia come prima e profondamente ancestrale caratteristica quella di sapere riconoscere i volti e, per questo, il fatto che una macchina sia in grado di crearne di perfettamente credibili è impressionante e, a suo modo, spaventoso. Non solo il GO quindi, ma anche il disegno di ciò che è più umano in assoluto, il volto, è diventato o sta diventando terreno di conquista per le macchine. Assieme con Douglas Hofstadter [Hofstadter 1979], che sostiene la impossibilità di replicare il pensiero umano, pensiamo che si tratti di qualcosa di differente dallintelligenza. Ma in ogni caso parliamo di una operazione in qualche modo intelligente che ha profondamente a che fare con il concetto di disegno e quindi con il più straordinario specchio che l'umanità ha a disposizione per provare a tentare di vedere e capire chi siamo, cosa siamo e come siamo fatti.

Ma perché tutto questo rappresenta una opportunità per il disegno?

Per rispondere a questa domanda basta pensare al fatto che le case produttrici di software, soprattutto nell'ambito di quello che viene definito Bim, stiano cercando con forza di riprodurre e applicare questi processi ‘antagonisti' degli algoritmi di intelligenza artificiale, alla progettazione architettonica.

Immaginando di dare in pasto alla macchina alcuni parametri e forme profonde, che potremmo definire tipologiche, del progetto architettonico esattamente come in pasto alla macchina sono state date le forme archetipiche del viso umano nell'esempio sopra citato, possiamo pensare di ottenere un progetto totalmente artificiale indistinguibile da quello pensato dalla mente umana.

Questo processo è nei fatti solo una evoluzione nella ricerca e definizione delle 'forme profonde' che è stata aperta dall'invenzione dei processi frattali negli anni '70. In quel momento si è scoperto che grazie ad una piccola equazione differenziale e ricorsiva il calcolatore era in grado di riprodurre la forma di una felce in un modo del tutto nuovo e diverso rispetto al processo del disegno tradizionale. Non solo di riprodurre la forma della felce ma anche di riuscire a riprodurne la struttura profonda, la sua forma intrinseca, soggiacente e nascosta (figg. 7- I2). Una operazione automatica ma che conteneva in sé un cambio di paradigma e il seme dell'intelligenza artificiale, in grado di cogliere la forma profonda di una pianta, in un modo che non è possibile spiegare con le classificazioni del disegno tradizionale.

\section{Conclusioni}

Quali sono gli scenari che si prospettano per il prossimo futuro? L'evoluzione della rivoluzione informatica nella rappresentazione è talmente rapida che non è possibile prevedere cosa potrà accadere nel prossimo futuro. Qualche punto fermo è però forse possibile individuarlo. 
Abbiamo detto innanzitutto che il disegnare e rappresentare è attività alta, profonda e in qualche modo mistica, che forse più di ogni altra influenza il modo in cui l'umano percepisce sé stesso.

Si è poi sottolineato come lo strumento che viene utilizzato non sia neutrale ma influenzi profondamente l'atto del disegnare e quindi l'atto dell'immaginare e del pensare.

Nel punto seguente abbiamo sottolineato come la prima rivoluzione informatica del disegno, ci abbia lasciato con strumenti software inadeguati al pensiero creativo.

Nella seconda parte abbiamo introdotto il tema degli algoritmi di intelligenza artificiale e della loro capacità di superare il pensiero umano in alcuni ambiti ritenuti, finora, ad esso riservati.

Abbiamo poi visto come il tema dellintelligenza artificiale, partendo dagli algoritmi frattali, sia anche tema di disegno in quanto capace di disegnare in modo autonomo forme naturali, come le felci e anche ritratti di volti umani e come già si stia cercando di sviluppare forme di disegno autonomo.

Quanto sopra descritto ci porta a formulare l'auspicio che l'applicazione degli algoritmi di intelligenza artificiale al disegno digitale si concretizzi in una evoluzione degli attuali sistemi che superi il concetto di 'un comando - una operazione' per arrivare a consentire una interazione disegnativa più semplice e profonda in grado di fare raggiungere al disegnatore informatico i livelli di trascendenza finora riservati al disegno classico.

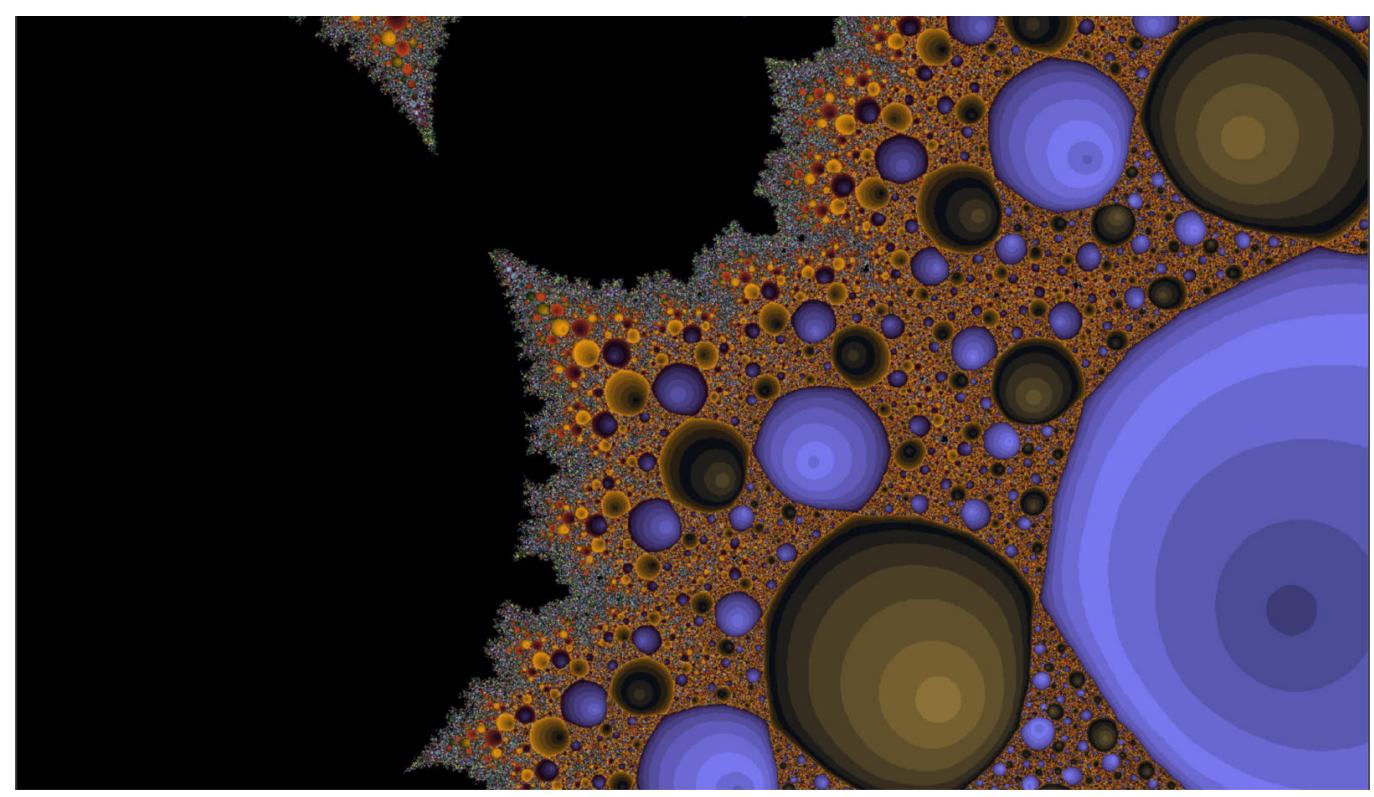

\section{Note}

$[$ I] <https://thispersondoesnotexist.com/>

\section{Riferimenti bibliografici}

Anceschi G. (1988). Monogrammi e figure. Firenze: Ponte alle Grazie.

Anceschi G. (a cura di). (1993). Il progetto delle interfacce. Oggetti colloquiali e protesi virtuali. Milano: Domus Accademy

Anceschi G. (20 I 6). Ulm e il gruppo T. In Horizonte. Rivista d'italianistica e di letteratura contemporanea. Uscita I, 20 I 6, pp. 225 -250.

Carpo M. (2017). The second digital turn. Design beyond intelligence. Massachusetts: MIT Press, 2017.

Focault M. (1983). This is not a pipe. Berkeley: University of California Press.

Herrigel E. ( 1 987). Lo Zen e il tiro con l'arco. Milano: Adelphi. 
Hofstadter D. (1979). Gödel, Escher, Bach: un'Eterna Ghirlanda Brillante. Una fuga metaforica su menti e macchine nello spirito de Lewis Carroll. Milano: Adelphi.

Iwata T., Yamabe T., Polojärvi M., Nakajima T. (20I0). Traditional games meet ICT: a case study on go game augmentation. In Coelho M., Zigelbaum J. TEl'I 0 Proceedings of the fourth international conference on Tangible, embedded, and embodied interaction, pp. 237-240.

Mc Luhan M. (1964). Understanding the media:The extensions of man. Berkeley: Gingko Press.

Munari B. (1968). Design e comunicazione visiva. Contributo a una metodologia didattica. Bari: Laterza.

Neves I. C., Rocha J.P. (20I3). The contribution of Tomas Maldonado to the scientific approach to design at the begginning of computational era. The case of the Hfg of Ulm. In Sousa J.P., Rocha J.P. Future traditions: Rethinking Traditions and Envisoining the Future in Architecture Throught the use of Digital Technologies (I st CAADE Regional International Workshop). University of Porto. pp. 39-50.

Neves I.C., Rocha J. P., Pinto Duarte J. (20I4). Computational Design Research in Architecture:The Legacy of the Hochschule fur Gestaltung, Ulm. In International journal of architectural computing. Issue I, volume 12, 2014, pp. I-25.

Norman D. (1988). La caffettiera del masochista. Psicopatologia degli oggetti quotidiani. Firenze: Giunti.

Panofsky E. (200I). La prospettiva come "forma simbolica" e altri scritti. Feltrinelli.

Sherman W.R., Craig A.B. (2002). Understanding Virtual Reality: Interface,Application, and Design. San Francisco: Morgan Kaufmann Publishers.

Autore

Gianluca Emilio Ennio Vita, Politecnico di Milano, gianluca.vita@polimi.it

Per citare questo capitolo:Vita Gianluca Emilio Ennio (2021). Disegno, Paradigma Informatico e Intelligenza Artificiale/Drawing, Computer Science Paradigm and Artificial Intelligence. In Arena A., Arena M., Mediati D., Raffa P. (a cura di). Connettere. Un disegno per annodare e tessere. Linguaggi Distanze Tecnologie. Atti del $42^{\circ}$ Convegno Internazionale dei Docenti delle Discipline della Rappresentazione/Connecting. Drawing for weaving relationship. Languages Distances Technologies. Proceedings of the 42th International Conference of Representation Disciplines Teachers. Milano: Franco Angeli, pp. 2740-2759. 


\title{
Drawing, Computer Science Paradigm and Artificial Intelligence
}

\author{
Gianluca Emilio Ennio Vita
}

Abstract

The fact that the computer has changed the practice, the theory and probably also the meaning of drawing is well known. The mutation is clearly still in progress and will continue to be so in the years to come, and it is also known that the transition from paper to computer has led to the loss of many of the qualities and specificities of drawing.

We are still in a phase of 'digestion' of the first paradigm leap, represented by the passage from 'classic' to 'computerized' design, but we are already about to witness a new technological and conceptual paradigm leap due to the development of the so-called Artificial Intelligence.

Like any technological revolution, this step will also present many unknowns accompanied by the hope of being able to obtain tools that are closer to architectural creative thinking than to the engineering-computer science typical of current software tools.

Keywords

artificial intelligence, drawing, go, algorithms.

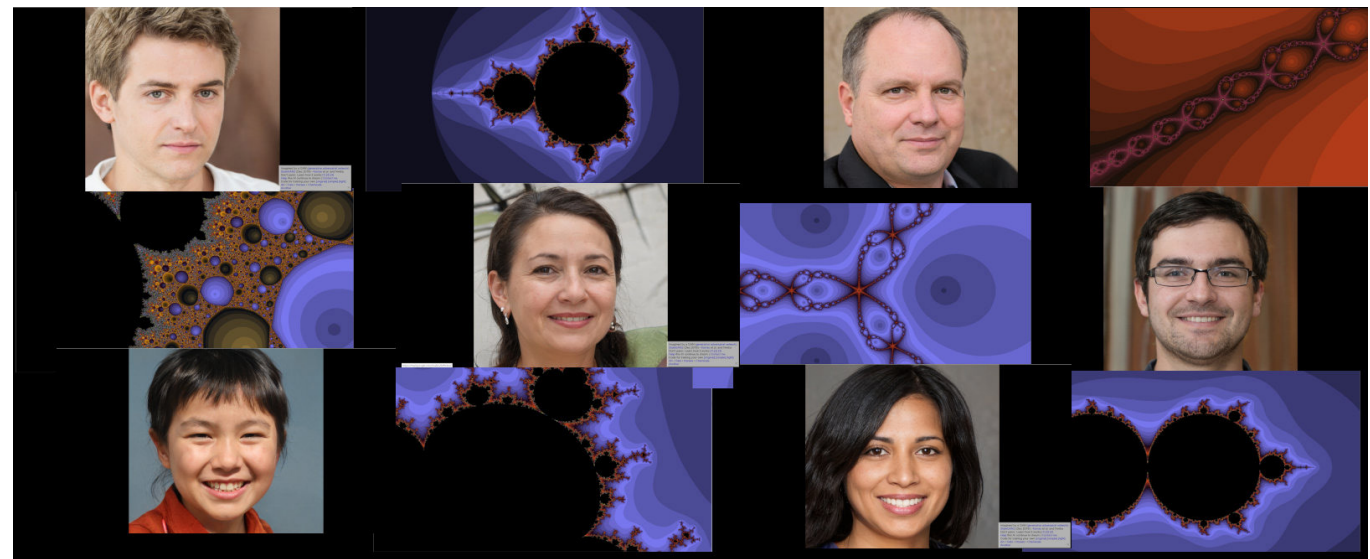




\section{Introduction}

When we look at the 'pipe that is not a pipe' designed by Magritte we wonder about what happens to our mind when we represent an object. We ask ourselves what that thing that is but at the same time is not' actually is, and then what is imagining, thinking, planning and therefore what is intelligence itself.

We believe that drawing cannot be considered a different thing from thinking and designing. Furthermore, we believe it is necessary to strongly say that drawing is project and thought in its highest expression.

It is not a question of melancholy of a past century nor superfluous considerations, in these years in which the brute force of technology overwhelms everything [Focault 1983].

It is not humanly possible to answer the question posed by Magritte's painting and truly understand what intelligence, mind and thought are. A 'higher level', not necessarily mystical one, would perhaps be necessary to understand it.

Fig. I. An example of a human face created by I.A. $<$ https://

thispersondoesnotexist. $\mathrm{com} />$ (accessed 2021 March 3).
Fig. 2. An example of a human face created by I.A. <https:// thispersondoesnotexist. $\mathrm{com} />$ (accessed 2021, March 3).
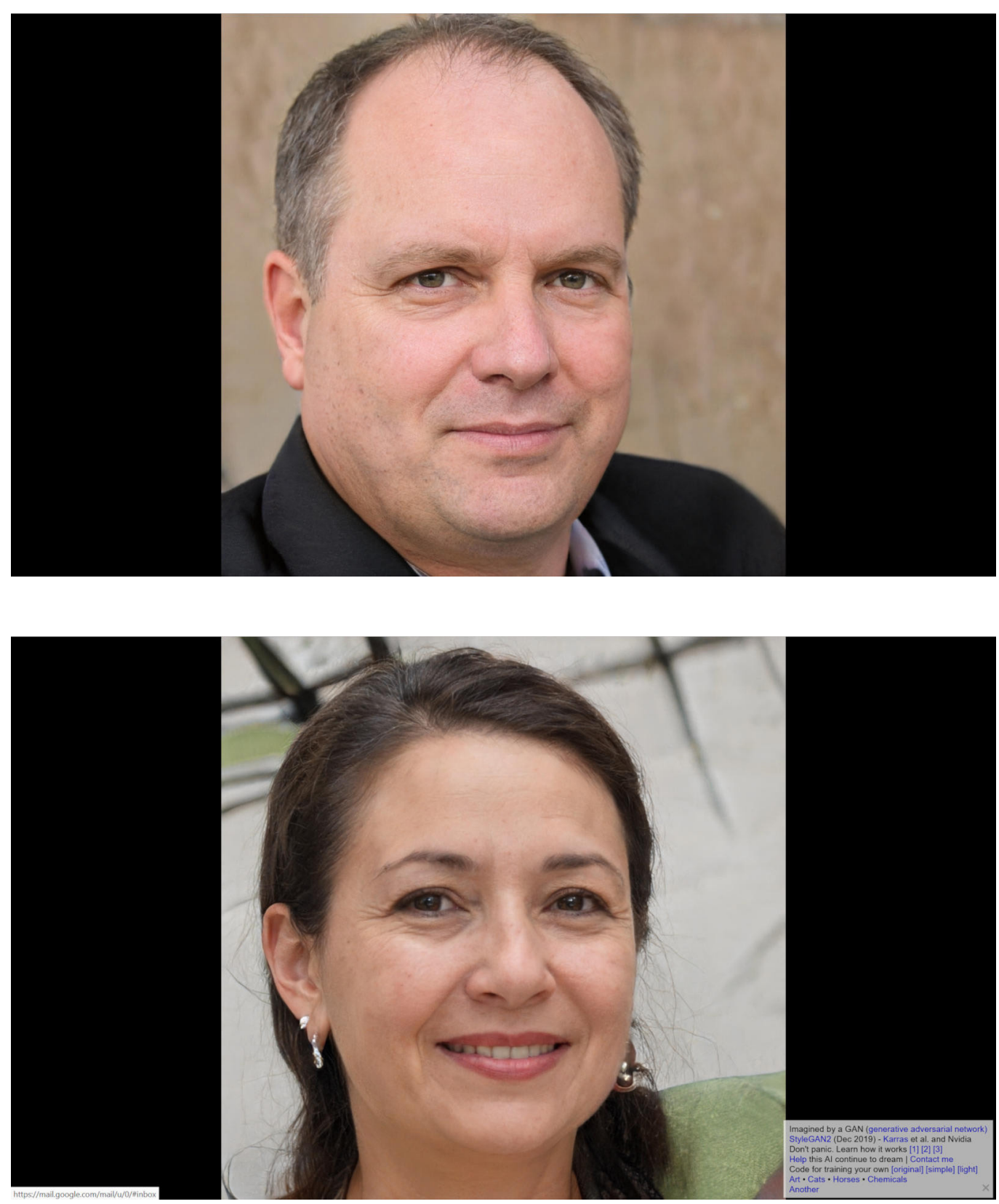
The mathematician Gödel has shown how a system cannot be self-demonstrating. To prove a system (or an entity) is necessary another entity superior to it. Gödel spoke of a mathematical entity, but the concept can certainly be extended to a metaphor for the human condition [Hofstadter 1979].

To try to read and understand this metaphorical higher level, drawing remains the most extraordinary form of exploration we have at our disposal. The tool that more than any other puts us in contact with ourselves, which helps us to understand who and what we are and to get closer to understanding the nature of intelligence.

Drawing allows us to go beyond the mirror and shows us the most hidden parts of ourselves but as the tool changes, what we see also changes and with it what we are able to understand about our human being [Anceschi 1988].

The computer design revolution, therefore, has not only represented a technical and practical transition from one way of drawing to another, but it has also sanctioned (as did per-

Fig. 3. An example of a human face create by I.A. $<$ https://

thispersondoesnotexist. com/> (accessed 2021 March 3).

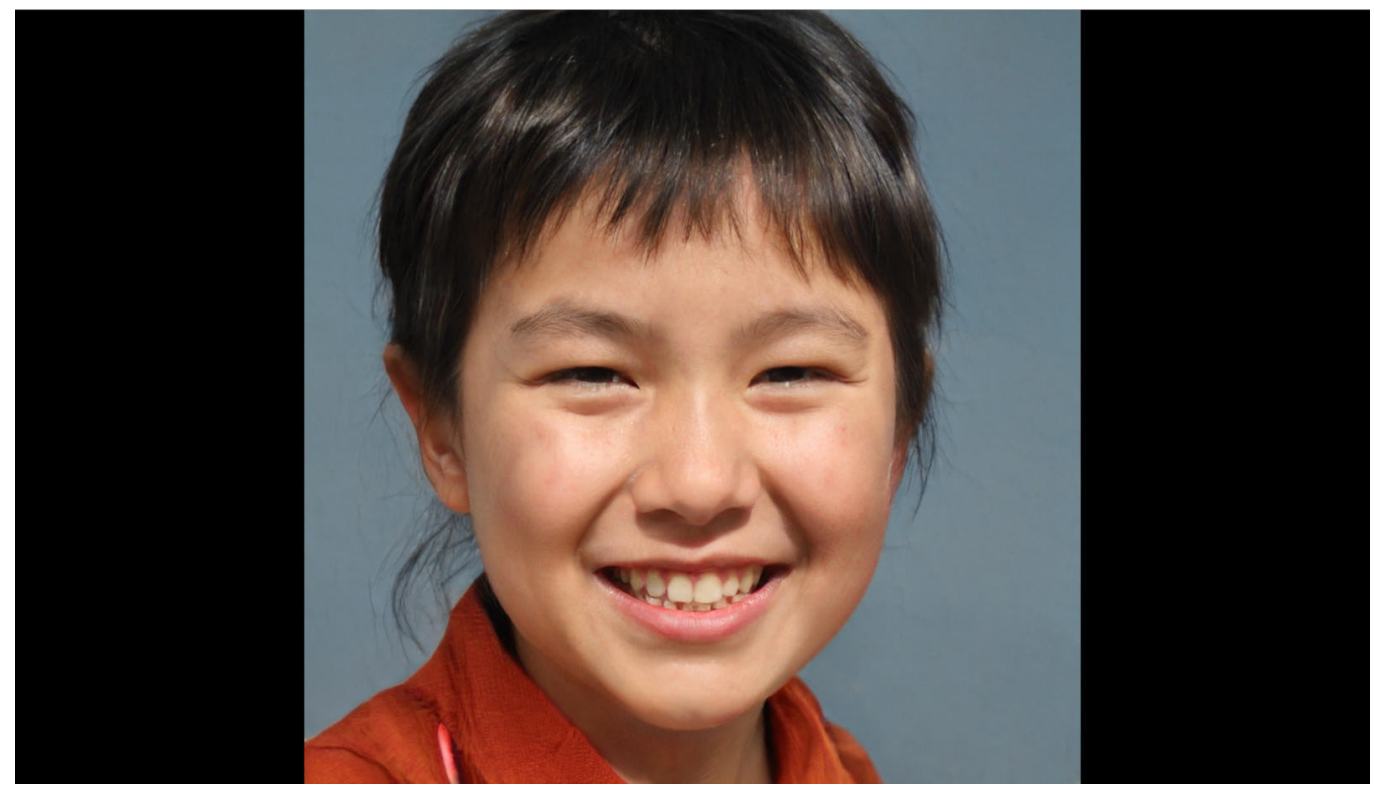

Fig. 4. An example of a human face created by I.A. <https:// by I.A. <https://
thispersondoesnotexist. com/> (accessed 2021, March 3).

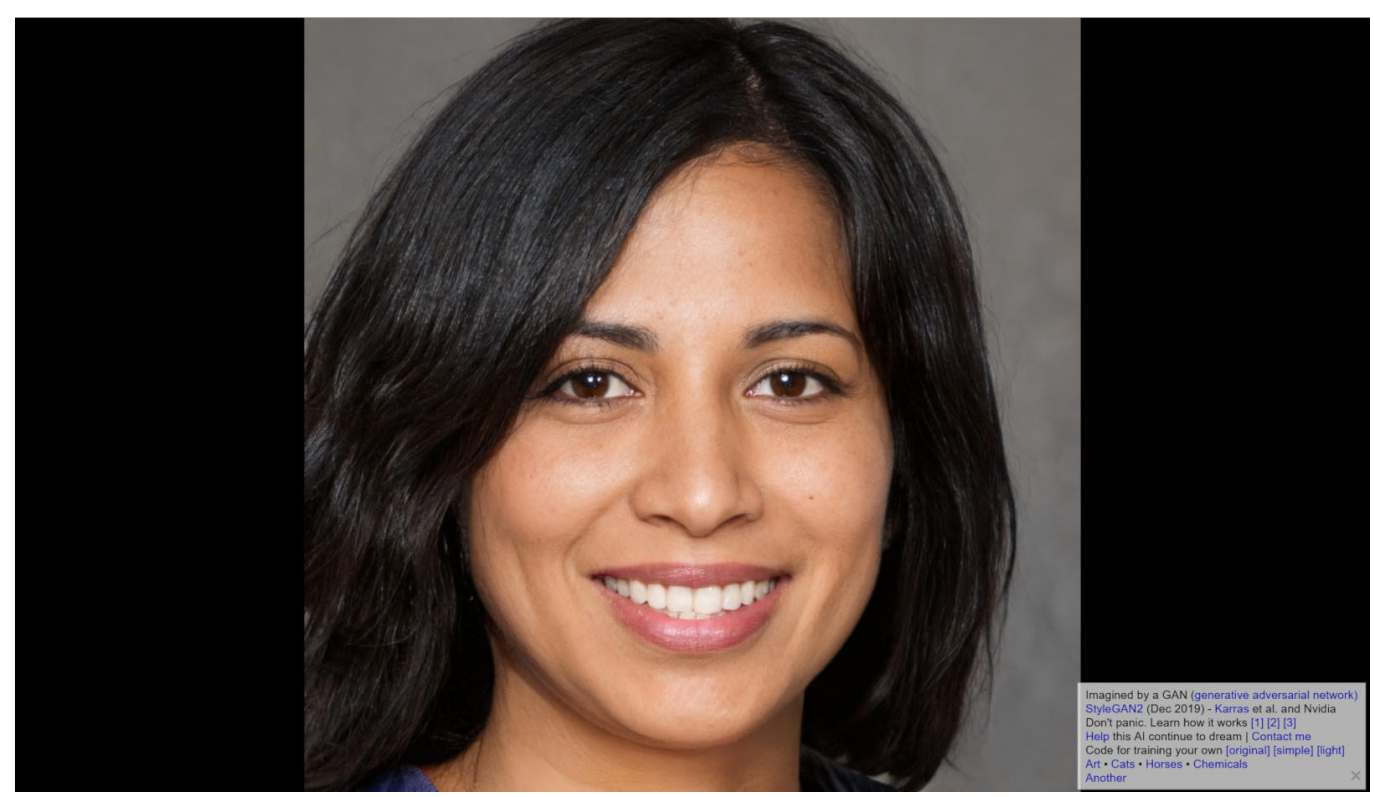


spective in its time) [Panofsky 200 I] a paradigm shift in the way of thinking and conceiving our mental universe and our human essence.

We are still in a phase of 'digestion' of the first paradigm shift from 'classic' to 'computerized' design, however, we are already about to witness a new technological and conceptual leap: that due to the development of algorithms of the so-called Artificial Intelligence, which represent an unknown but also the possibility of freeing ourselves from the limits of the current digital design.

\section{The digital paradigm shift}

It is clear that drawing is in a phase of paradigm change and that digital techniques are changing the very idea of drawing. Indeed, we can already speak of this event in the past. Digital techniques have changed the way we draw and conceive the act of drawing and are
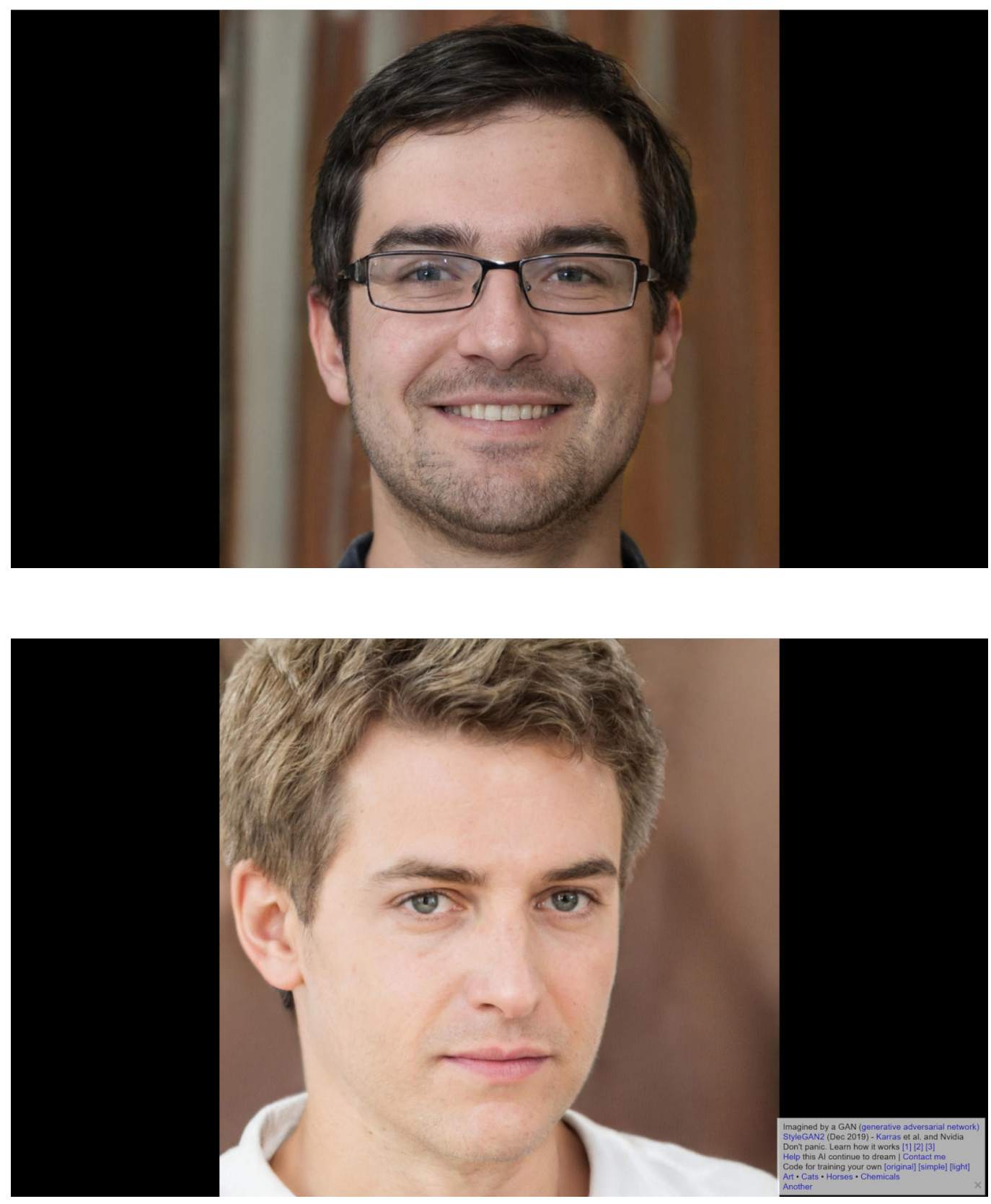


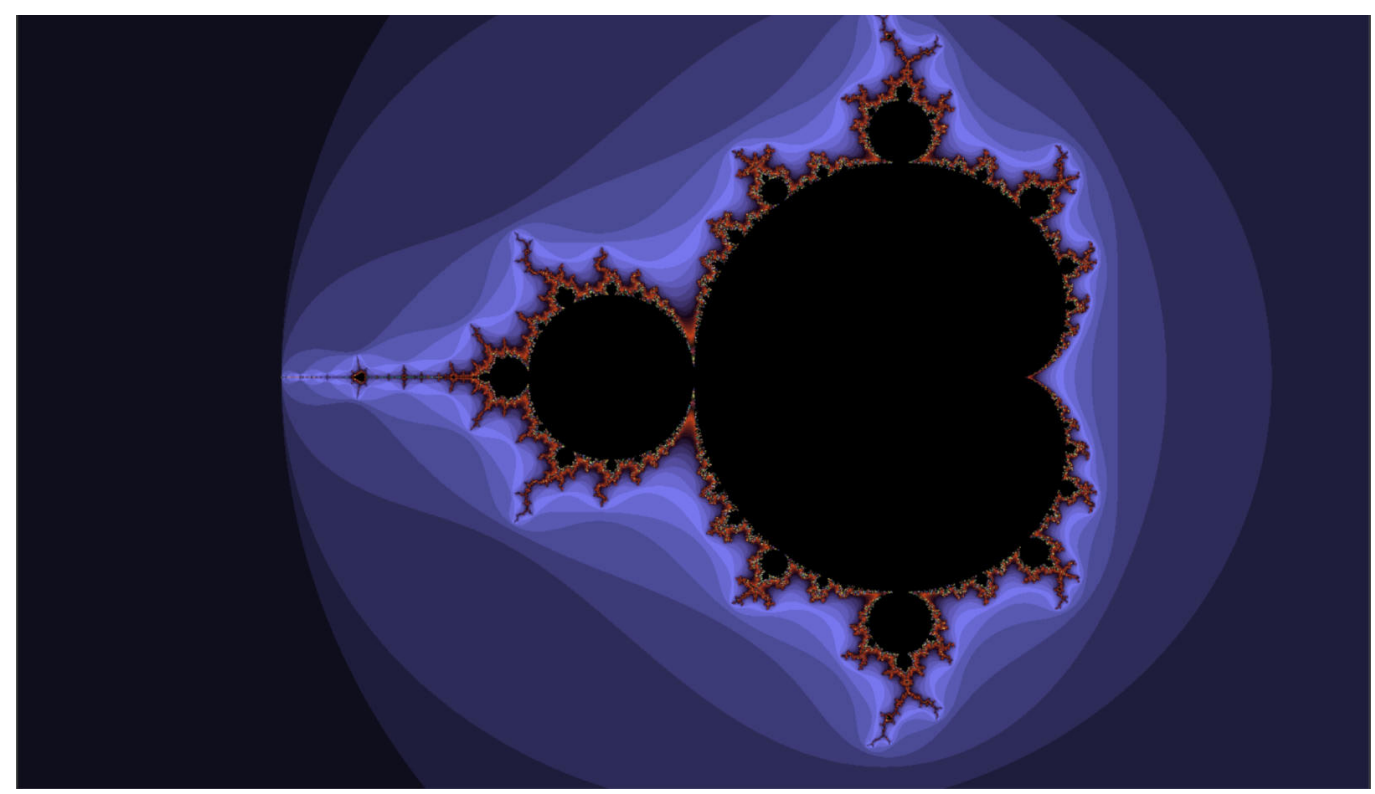

still changing it today, with great problems caused by the fact (forgive the oversimplification) that digital drawing tools were not made by designers but by computer scientists.

The whole process of development of the main drawing software has followed, starting from the 1970s, a uniform parable in which it began to 'put real tools inside the computer'. This process is still evident today in the commands evidently inspired by the drafting machine as in Autocad, or by the darkroom as in Photoshop.

But it was only a first phase, computer action then became more and more abstract following logics and mental structures that are not those of the designer [Norman 1988].

Not being able to develop this topic here, we think it is enough as an example to focus on the furious need for precision that drawing with any Cad software requires. Vector Cad drawing is for many the archetype of 'drawing with the computer' and requires a constant obsessive and crazy supply of very exact coordinates: Distance! Distance! Distance! The designer does not think so. For the draftsman the proportion comes first and only after the measure.

We can say that without a doubt today we use inadequate drawing tools that violate the very nature of drawing. Sometimes it happens to get caught up in the claustrophobic anguish of being in a flow of which we know the beginning and we can only guess the end with the feeling of being able to travel only one path, established and decided by those

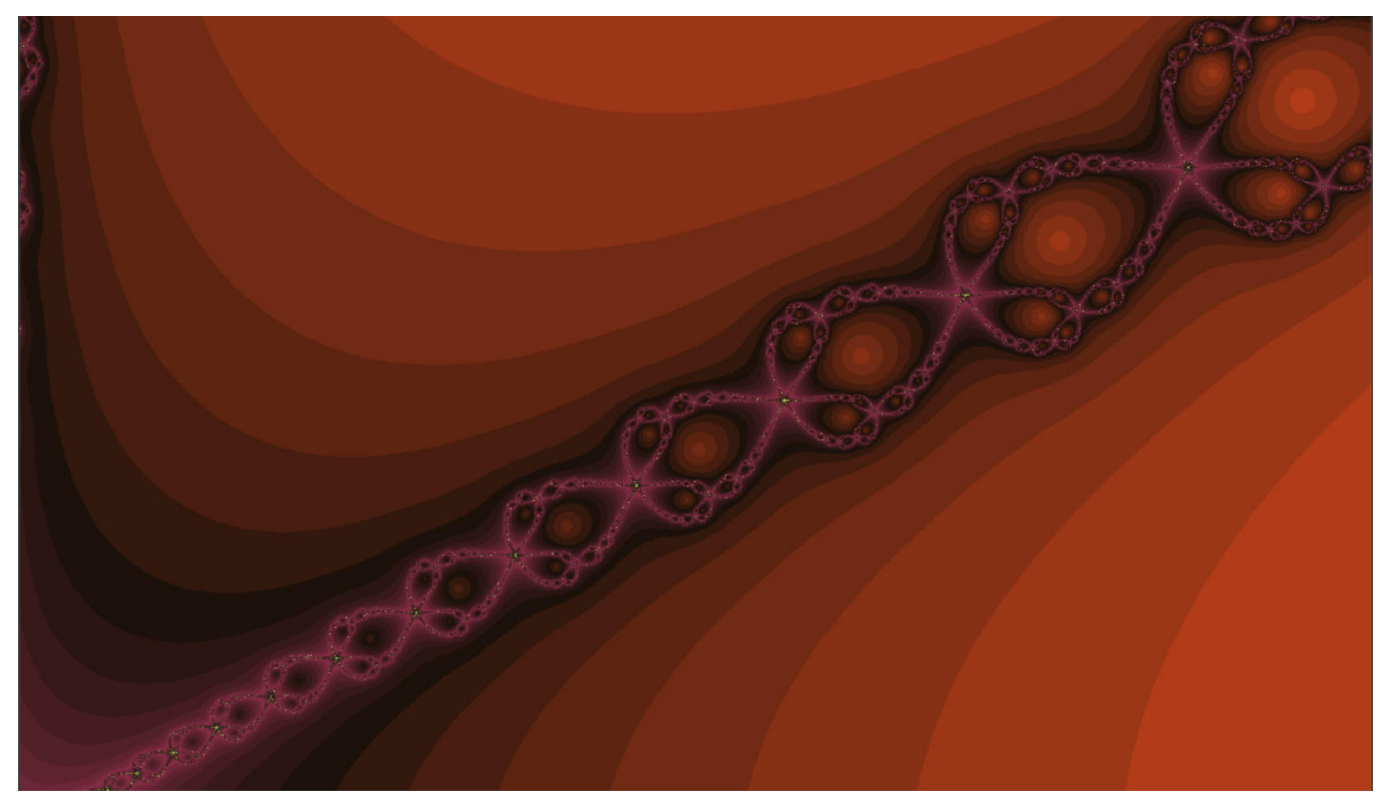


Fig. 9. An example of a fractal created with Xaos software.

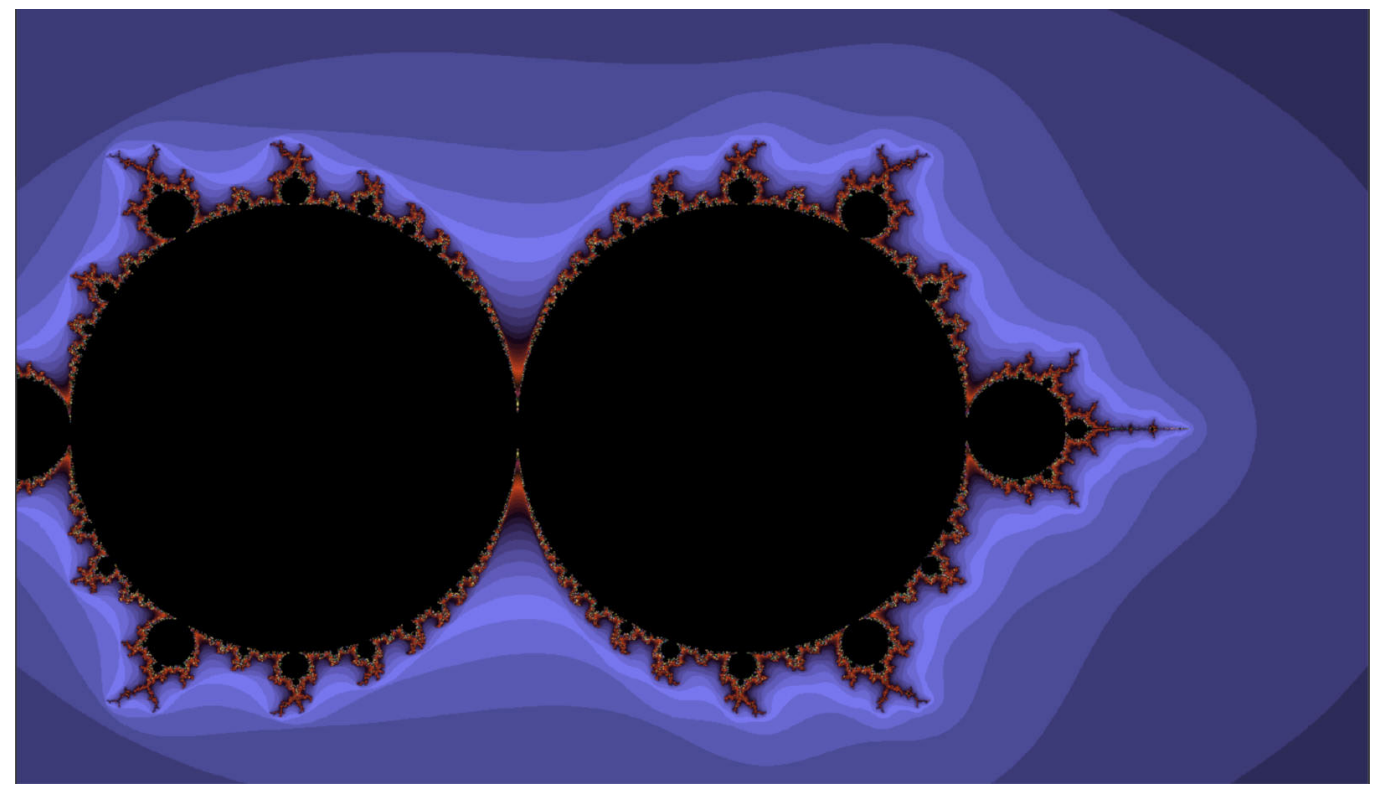

who produce the IT tool. We reiterate that it is not a simple process of replacing one tool with another because, "the media is the message" [Mc Luhan 1964] or if you prefer, because drawing is thinking, imagining and exploring the 'higher level' so if you draw badly, you think badly.

There have been attempts to bring software closer to human thinking, but the results are far from being, in our opinion, satisfactory. Interesting can be the example of the SketchUp software that has tried, with some success, to get out of the logic 'one function - one command' to propose an interaction in which the software tries to guess what the Person (a term we prefer to hateful 'user') intends to do from the position and movement of the mouse.

We can also mention, by way of example, the BIM software which while trying to represent a method of simplification and rationalization of designing buildings with the computer, collapse under the weight of their excessive complexity.

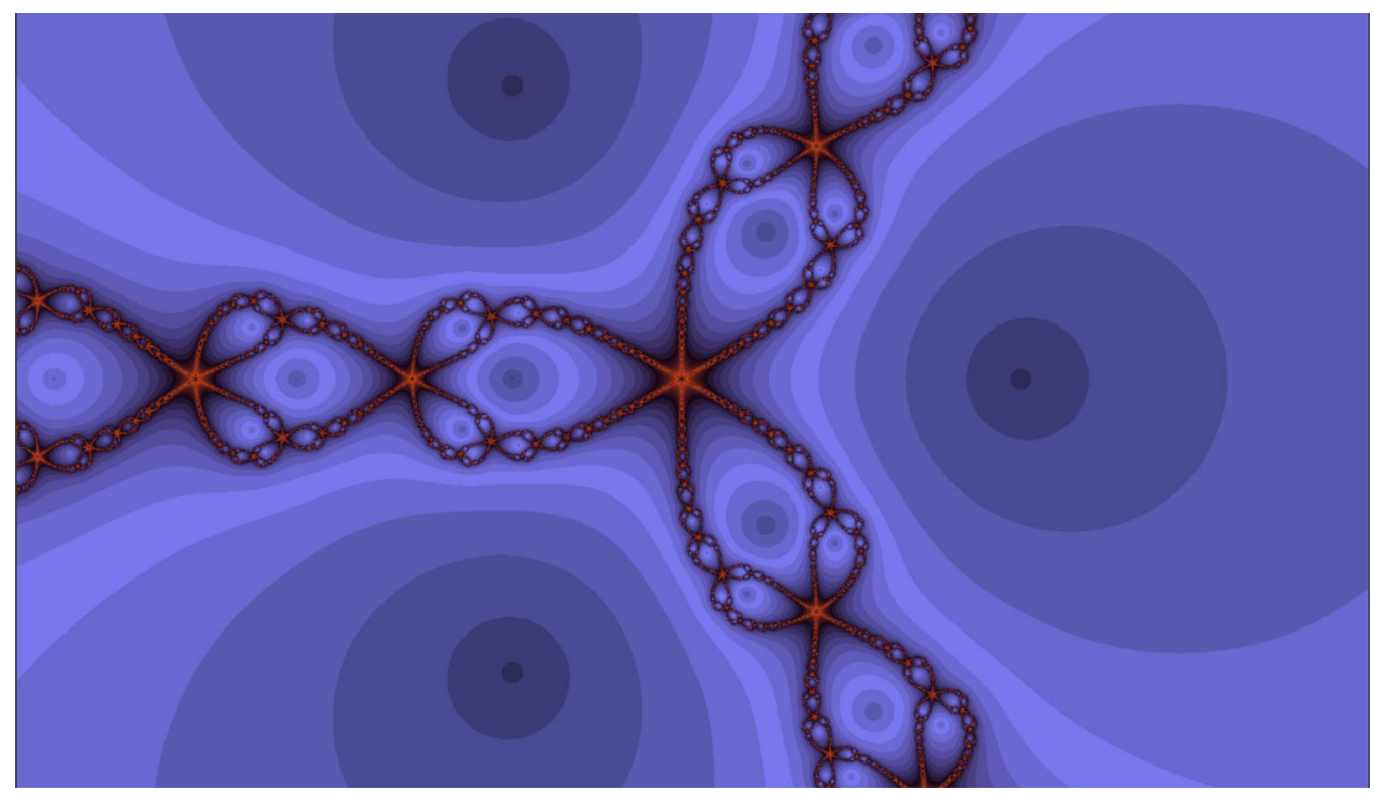


The basic concept is excellent, based on the idea that if I draw a line and tell the computer that that line is a wall, and then I tell it that the wall is made with certain materials, I have an infinitely modifiable and updatable model in which I can then insert doors, windows, add and subtract floors, etc. All in an interactive way with the great advantage of not having to redo the technical drawings every time.

Unfortunately, the result of this effort, for reasons due to the profound nature of the Bim process, is the attempt to make a $1: 1$ scale model of the building that transforms the software from a drawing tool into a sort of huge three-dimensional Excel file.

If the programmers had read Borges's short story about the Chinese emperor who wanted to make a I:I scale model of the empire, perhaps the result would have been better.

In this context of drawing tools that are not suited to his way of thinking, the figure of the architect is not only in a strong need for adaptation (something to which he has been accustomed for some time and which indeed, as claimed by Mario Carpo [Carpo 2017], has managed with great skill in what he calls the first digital turn) but is, let's face it bluntly, in danger of extinction because the tools he uses convey a way of thinking that is profoundly different from his. We are in an era in which the digital tool seeks, in a more or less conscious way, to erode the very character of the architect's thought as a connection between artistic and technological thought and to transform it into a sort of performer-decorator to whom they come at best, marginal tasks of 'fashion' and 'taste' are delegated. Everything else, the culture and profound knowledge of architecture seem like initiated sophisms, conversations between philosophers or ikebana masters, dedicated to an abstract and detached aesthetic.

\section{Are the machines learning to draw?}

Can we hope that the development of so-called artificial intelligence and the algorithms connected to it will, in the near future, allow us to use tools that are less tied to 'rigid' ways of thinking that are imposed on us by the digital design methods we have talked about so far? Machines have now surpassed human capacity in the game of chess, and even the oriental game of Go, apparently even deeper in exploring human intuition, has been conquered by artificial intelligence.

Playing chess, or Go, for the human mind involves the adoption of 'chords' of thought that go beyond the analysis of possible moves. The chess master plays thinking about functional

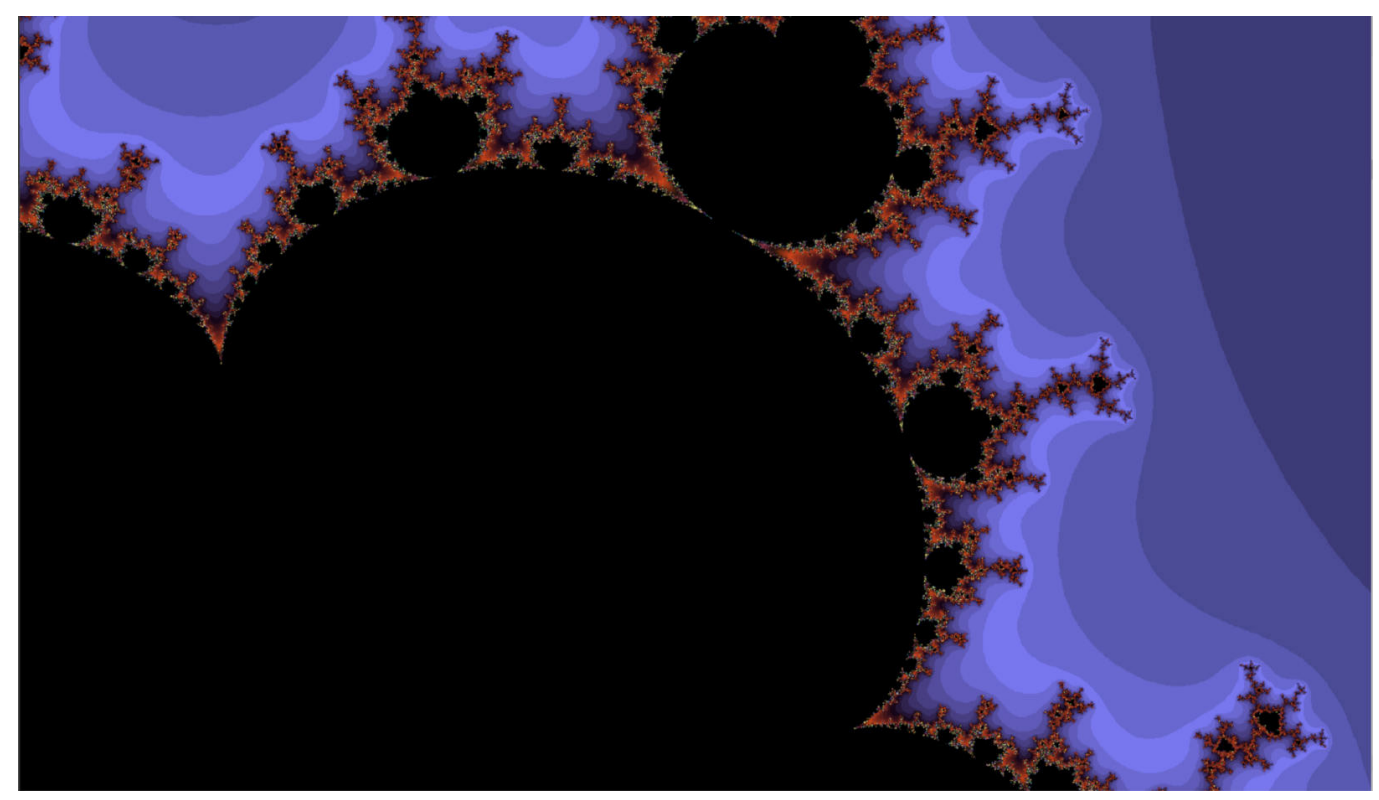


compositions that cannot be described as a tree of possibilities (if I do this, the other does that ... then I do this, etc ...) but as configurations of virtual forms that lead to intuit the shape of the next move.

"Move 37 was so shocking that Lee had come to wonder what creativity in Go was. After losing the second game as well, he decided to reunite with some Go pros and analyze the match". And discuss the meaning and philosophy of the game itself (from the description of the first game in which the Alpha GO artificial intelligence beat the Go World Champion Lee Se-Dol).

What relationship, however, links the practice of drawing with what happens to the game of Go or chess? The relationship is quickly becoming evident.

If you search the web for the page thispersondoesnotexist [I], images of people who simply do not exist appear, reloading the page several times. They are images created in a totally artificial way through the use of 'contrasting algorithms' that perform an impressive operation, creating artificial faces almost always perfectly credible and indistinguishable from real faces. This is not a composition operation like the one you could do with Photoshop, it is a real archetypal creation operation (figs. I-6).

It is a drawing operation that is hard not to define as intelligent. The stain once again succeeds in appropriating an operation reserved for the abilities of the human intellect: drawing faces, one of the operations that most characterizes human thought and detaches it from bestiality. It is certain that the human mind has as its first and deeply ancestral characteristic that of knowing how to recognize faces and, for this reason, the fact that a machine is able to create perfectly credible ones is impressive and, in its own way, frightening. Not only the GO then, but also the design of what is most human of all, the face, has become or is becoming a conquering ground for machines. We think (with Douglas Hofstadter [Hofstadter 1979], that says it is impossible to replicate human thought) that it is something different from intelligence. But in any case, we are talking about a somewhat intelligent operation that has profoundly to do with the concept of drawing and therefore with the most extraordinary mirror that humanity has at its disposal to try to see and understand who we are, what we are. and how we are made.

But why does all this represent an opportunity for drawing?

To answer this question, just think of the fact that software manufacturers, especially in the context of what is called Bim, are trying hard to reproduce and apply these 'antagonistic' processes of artificial intelligence algorithms to architectural design.

Imagining to feed the machine some parameters and deep forms, which we could define typological, of the architectural project exactly as the archetypal shapes of the human face were fed to the machine in the example cited above, we can think of obtaining a totally artificial project indistinguishable from that thought by the human mind.

This process is in fact only an evolution in the research and definition of 'deep forms' that was opened by the invention of fractal processes in the 1970s. At that moment it was discovered that thanks to a small differential and recursive equation the computer was able to reproduce the shape of a fern in a completely new and different way than the traditional drawing process. Not only to reproduce the shape of the fern but also to be able to reproduce its deep structure, its intrinsic, underlying and hidden form. (figs. 7- 12)

An automatic operation but which contained within itself a paradigm shift and the seed of artificial intelligence, capable of capturing the deep shape of a plant, in a way that cannot be explained with the classifications of traditional design.

\section{Conclusions}

What are the scenarios that lie ahead for the near future? The evolution of the information revolution in representation is so rapid that it is not possible to predict what will happen in the near future. However, it is perhaps possible to identify some fixed points.

We said first of all that drawing and representing is a high, profound and somehow mystical 
activity, which perhaps more than any other influences the way in which the human perceives himself.

It was then emphasized that the tool used is not neutral but profoundly influences the act of drawing and therefore the act of imagining and thinking.

In the following point we underlined how the first computer revolution of design left us with software tools that were inadequate for creative thinking.

In the second part we introduced the topic of artificial intelligence algorithms and their ability to overcome human thought in some areas considered, up to now, reserved for it.

We then saw how the theme of artificial intelligence, starting from fractal algorithms, is also a drawing theme as it is able to autonomously draw natural shapes, such as ferns and also portraits of human faces and how we are already trying to develop shapes of autonomous drawing.

The above leads us to formulate the hope that the application of artificial intelligence algorithms to digital drawing will materialize in an evolution of current systems that goes beyond the concept of 'one command - one operation' to allow for a more effective design interaction. simple and profound able to make the computer designer reach the levels of transcendence until now reserved for classic design.

Fig. 12. An example of a fractal created with Xaos software.

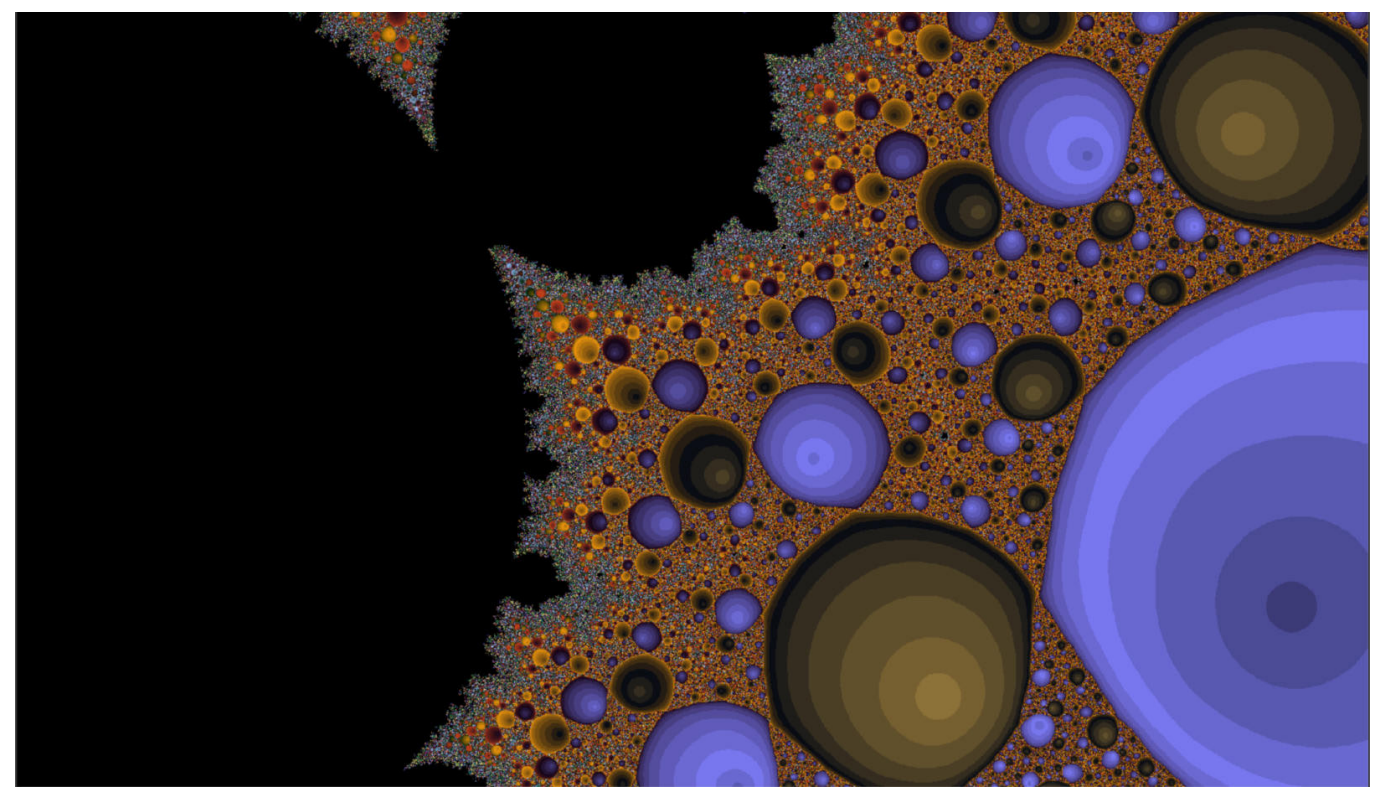

Notes

$[\mathrm{I}]<$ https://thispersondoesnotexist.com/>

\section{References}

Anceschi G. (1988). Monogrammi e figure. Firenze: Ponte alle Grazie.

Anceschi G. (a cura di). (1993). Il progetto delle interfacce. Oggetti colloquiali e protesi virtuali. Milano: Domus Accademy

Anceschi G. (20 I 6). Ulm e il gruppo T. In Horizonte. Rivista d'italianistica e di letteratura contemporanea. Uscita I, 20 I 6, pp. 225 -250.

Carpo M. (2017). The second digital turn. Design beyond intelligence. Massachusetts: MIT Press, 2017.

Focault M. (1983). This is not a pipe. Berkeley: University of California Press.

Herrigel E. (1987). Lo Zen e il tiro con l'arco. Milano: Adelphi. 
Hofstadter D. (1979). Gödel, Escher, Bach: un'Eterna Ghirlanda Brillante. Una fuga metaforica su menti e macchine nello spirito de Lewis Carroll. Milano: Adelphi.

Iwata T., Yamabe T., Polojärvi M., Nakajima T. (20I0). Traditional games meet ICT: a case study on go game augmentation. In Coelho M., Zigelbaum J. TEl'I 0 Proceedings of the fourth international conference on Tangible, embedded, and embodied interaction, pp. 237-240.

Mc Luhan M. (1964). Understanding the media:The extensions of man. Berkeley: Gingko Press.

Munari B. (1968). Design e comunicazione visiva. Contributo a una metodologia didattica. Bari: Laterza.

Neves I. C., Rocha J.P. (20I3). The contribution of Tomas Maldonado to the scientific approach to design at the begginning of computational era. The case of the Hfg of Ulm. In Sousa J.P., Rocha J.P. Future traditions: Rethinking Traditions and Envisoining the Future in Architecture Throught the use of Digital Technologies (I st CAADE Regional International Workshop). University of Porto. pp. 39-50.

Neves I.C., Rocha J. P., Pinto Duarte J. (20I4). Computational Design Research in Architecture:The Legacy of the Hochschule fur Gestaltung, Ulm. In International journal of architectural computing. Issue I, volume 12, 2014, pp. I-25.

Norman D. (1988). La caffettiera del masochista. Psicopatologia degli oggetti quotidiani. Firenze: Giunti.

Panofsky E. (200I). La prospettiva come "forma simbolica" e altri scritti. Feltrinelli.

Sherman W.R., Craig A.B. (2002). Understanding Virtual Reality: Interface,Application, and Design. San Francisco: Morgan Kaufmann Publishers.

Author

Gianluca Emilio Ennio Vita, Politecnico di Milano, gianluca.vita@polimi.it

To cite this chapter. Vita Gianluca Emilio Ennio (2021). Disegno, Paradigma Informatico e Intelligenza Artificiale/Drawing, Computer Science Paradigm and Artificial Intelligence. In Arena A., Arena M., Mediati D., Raffa P. (a cura di). Connettere. Un disegno per annodare e tessere. Linguaggi Distanze Tecnologie. Atti del $42^{\circ}$ Convegno Internazionale dei Docenti delle Discipline della Rappresentazione/Connecting. Drawing for weaving relationship. Languages Distances Technologies. Proceedings of the 42th International Conference of Representation Disciplines Teachers. Milano: Franco Angeli, pp. $2740-2759$ 
II secondo volume dedicato al $42^{\circ}$ Convegno Internazionale della Unione Italiana per il Disegno riprende il tema 'Connettere' riflettendo sul focus Disegno: Linguaggi, Distanze, Tecnologie, suggeritoci anche dalla condizione in remoto che ci ha visti nella impossibilità di riunirci fisicamente, e ha dato spunto e rilancio al convegno stesso.

I linguaggi, le distanze, le tecnologie ci portano a rivedere costantemente le dinamiche che regolano le connessioni col disegno e il contesto storico e sociale che in quest'ultimo anno e mezzo lo ha connotato.

Disegno e Linguaggi visivi letti alla luce delle molteplici articolazioni che ne derivano. Come una metafora del linguaggio, il disegno allude, illude, rivela e inganna.

Disegno e Distanze ci riporta alle pratiche del rilevamento, ma anche al significato della parola distanziamento con tutto quello che ne consegue per aiutarci a sopperire l'invalicabile separatezza fisica.

Disegno e Tecnologie porta alla evidenza del mondo digitale, letto nelle sue implicazioni con le diverse scienze, tramutando il computer da strumento di calcolo a fonte espressiva di comunicazione, anche artistica, per l'elaborazione di una nuova estetica digitale.

Nel volume si intrecciano le discipline, e si intrecciano i settori della ricerca: un perfetto percorso di contaminazione in cui entrano in gioco competenze molto diversificate.

E così le tre parole, 'linguaggi', 'distanze', 'tecnologie', creano un cerchio perfetto che, ruotando attorno al disegno in modo sincrono e spesso sovrapponibile, riprende e rilancia le 'connessioni' per annodare e tessere nuovi e antichi disegni.

The second volume dedicated to the $42^{\text {nd }}$ International Conference of the Unione Italiana per il Disegno takes up the theme of 'Connecting' in reflecting on the topic Drawing: Languages, Distances, Technologies, also suggested by the remote condition that made it impossible for us to meet physically, and prompted and relaunched the conference itself.

Languages, distances, technologies lead us to constantly review the dynamics that regulate the connections with drawing, and the historical and social context that in the last year and a half has characterized it.

Drawing and visual Languages seen in the light of the multiple articulations that derive from them. Like a metaphor for language, drawing alludes, illudes, reveals and deceives.

Drawing and Distances brings us to the practices of surveying, but also to the meaning of the word distancing, with all that it implies, to help us overcome the insurmountable physical separateness.

Drawing and Technologies leads to the evidence of the digital world, viewed in its implications with the different sciences, transforming the computer from an instrument of calculation into an expressive source of communication, even artistic, for the development of a new digital aesthetic.

In this volume, disciplines are intertwined, and even research sectors: a perfect path of contamination in which very different competencies come into play.

And thus these three words, 'languages', 'distances', 'technologies', create a perfect circle that, rotating around drawing in a synchronous and often overlapping way, resumes and relaunches connections for creating new and ancient drawings. 